\title{
Responsibility for private sector adaptation to climate change
}

\author{
$\underline{\text { Tina Schneider }}^{1}$
}

\begin{abstract}
The Intergovernmental Panel on Climate Change (2007) indicates that vulnerable industries should adapt to the increasing likelihood of extreme weather events along with slowly shifting mean annual temperatures and precipitation patterns, to prevent major damages or periods of inoperability in the future. Most articles in the literature on business management frame organizational adaptation to climate change as a private action. This makes adaptation the sole responsibility of a company, for its sole benefit, and overlooks the fact that some companies provide critical goods and services such a food, water, electricity, and medical care, that are so vital to society that even a short-term setback in operations could put public security at risk. This raises the following questions: (1) Who is responsible for climate change adaptation by private-sector suppliers of critical infrastructure? (2) How can those who are identified to be responsible, actually be held to assume their responsibility for adapting to climate change? These questions will be addressed through a comprehensive review of the literature on business management, complemented by a review of specialized literature on public management. This review leads to several conclusions. Even though tasks that formerly belonged to the state have been taken over by private companies, the state still holds ultimate responsibility in the event of failure of private-sector owned utilities, insofar as they are "critical infrastructure." Therefore, it remains the state's responsibility to foster adaptation to climate change with appropriate action. In theory, effective ways of assuming this responsibility, while enabling critical infrastructure providers the flexibility adapt to climate change, would be to delegate adaptation to an agency, or to conduct negotiations with stakeholders. In view of this theory, Germany will be used as a case study to demonstrate how private-sector critical infrastructure providers can plan and implement climate change adaptation in practice, through the regulatory modes of "negotiations" and "enforced self-regulation."
\end{abstract}

Key Words: adaptation to climate change; business; critical infrastructure; Germany; public responsibility

\section{INTRODUCTION}

Vulnerable industries should adapt to an increasing likelihood of extreme weather events and slowly shifting mean annual temperatures and precipitation patterns, to prevent major damage or outages in the future. This is one of the conclusions of the Intergovernmental Panel on Climate Change's (IPPC) Fourth Assessment Report on Climate Change (2007), and it is particularly true for those companies operating in the energy, water, security, transport, logistics systems, finance, insurance, food supply, health care, information, telecommunications, and media sectors, all of which are critical infrastructure providers. According to Dunn-Cavelty (2008), a private company is deemed to provide critical infrastructure if the "systems or assets are so vital to a country that any extended incapacity or destruction of such systems would have a debilitating impact on security, the economy, national public health or safety, or any combination of the above" (Dunn-Cavelty 2008:40).

Without adequate adaptation strategies to climate change impacts, these critical industries run a significant risk of high levels of both direct and indirect loss, depending on the predictability and duration of a breakdown. In a case where there is a lack of alternative suppliers, a breakdown in critical infrastructures, for example, public security, food, energy, or water, would have severe consequences for a large number of stakeholders. An enterprise can likewise be considered to be critical infrastructure if it produces or processes harmful substances or hazardous waste that has the capability to seriously contaminate the natural and built environment, for example, lead and cadmium (Lewis 2006, Boin and McConnell 2007, Tagarev and Pavlov 2007, Van der Lei et al. 2010).

Following the IPCC (2007), climate change adaptation can be defined as: "adjustments in natural or human systems in response to actual or expected climatic stimuli or their effects, which moderate harm or exploit beneficial opportunities." Therefore, climate change may generate new phenomena, both in terms of opportunities, for example, new markets and services for adaptation measures such as flexible water pipelines, and also in terms of risks, for example, new pathogens and pests (Termeer et al. 2011). Climate change adaptation strategies proposed by the literature on business management primarily result in postponing adaptation for a decade while waiting for new research findings, or reactively adapting organizational assets. Another proposed approach is not to directly undertake adaptation measures, but rather to cover damages through insurance and therefore transfer the risk to a third party, for example through catastrophe bonds (Linnenluecke et al. 2012). None of these approaches are appropriate for providers of critical infrastructure, as the default costs would be much too high. For this reason, adaptation to the impacts of climate change by critical infrastructure providers needs to be initiated in advance, as a precautionary measure. "Furthermore, aid or compensation in case of extreme events are not adaptation measures per se, since damage is not prevented by these measures" (Aakre and Rübbelke 2010:770).

Empirical research at the organizational level (Berkhout et al. 2006, Fichter and Stecher 2011, Pechan et al. 2011, Weinhofer and Busch 2012) indicates that most companies postpone climate change adaptation or rely on reactive adaptation measures (predominantly insurance) and that efficiency objectives usually rule out proactive adaptation measures in terms of ensuring resilient long-term provision of critical infrastructure. However, although the private sector is reluctant to implement proactive adaptation measures, critical goods and services require a proactive approach. In view of this, the following questions arise: (1) Who is responsible for climate change adaptation of private-

${ }^{1}$ Department of Business Administration, Economics, and Law, Oldenburg University 
sector critical infrastructure providers? (2) How can those who are identified to be responsible, actually be held to assuming their responsibility for climate change adaptation?

\section{METHODS}

This research is divided into two parts: a theoretical part based on a literature review, and a case study. The literature review was primarily based on an analysis of business management journals concerned with environmental issues (Table 1). These included Ecological Economics, Business and Society, Business Strategy and the Environment, Long Range Planning, the interdisciplinary journal Climatic Change, and additional monographs. Publications over the past 15 years were searched by using the key words "adaptation to climate change," "critical infrastructure," "utilities," and "public responsibility." This was complemented by an analysis of the literature from public management, including the International Journal of Critical Infrastructure Protection, Environment and Planning C, Public Choice, and additional literature (Table 1). In view of the literature review, the responsibilities for private-sector critical infrastructure adaptation to climate change are assigned, and Germany is used as a case study that consists of an explorative review of policy and research documents addressing private-sector critical infrastructure adaptation to climate change.

\section{RESULTS OF LITERATURE REVIEW}

Research on adaptation to climate change at the microlevel of businesses is in its early stages. A review of business management literature from 2006-2010 reveals a considerable increase in the number of articles addressing both the perception and the strategic and operational processing of climate change by businesses (Stecher and Fichter 2010). Most articles in the research field of "organizational adaptation to climate change" analyze private-sector adaptation strategies and measures with an almost exclusive focus on how businesses benefit from such undertakings. Accordingly, research questions focused on the allocation of responsibility for climate change adaptation in cases where adaptation is lacking, or on the effects of undertaking or ignoring adaptation measures on the rest of society, are implicitly excluded from the existing business management research on climate change adaptation (Sheffi 2005, Berkhout et al. 2006, Winn et al. 2010, Pechan et al. 2011, Weinhofer and Busch 2012). By setting the research focus in such a way, the business management literature frames climate change adaptation as an exclusively private action with exclusively private beneficiaries, whereas mitigation is primarily framed as a public good characterized by joint consumption where it is infeasible to exclude consumers, given that every society in the world will benefit from reduced greenhouse gas emissions. Most articles focused on businesses at the microlevel consider their adaptation to climate change to be solely a private good, characterized by exclusive consumption and the feasible exclusion of consumers (Ostrom and Ostrom 1997, Hasson et al. 2010). Given that the business management literature on climate change adaptation rarely accounts for the vital importance of companies that provide critical services to the public when framing private-sector climate change adaptation as a public good, it does not address the question of who is ultimately responsible for climate change adaptation in cases where the private sector is providing goods and services for public benefit. Rare exceptions to this may exist in the economics literature, for example, Arnell and Delany 2006, Osberghaus et al. 2010, Tompkins and Eakin 2012.

Conversely, the literature on public management discusses the responsibility for the operational continuation of critical goods and services providers in times of crisis. By expanding the public management literature review to include the specific topics of civil security and critical infrastructures, it is revealed that, whereas the business management literature predominantly neglects the public dimension of climate change adaptation, the literature on civil security and critical infrastructures largely neglects the topic of climate change adaptation (Barnett 2003, Lewis 2006, Tagarev and Pavlov 2007, Dunn-Cavelty 2008, Van der Lei et al. 2010). Articles addressing policy and management tools focus predominantly on security threats drawn from real-life past experience, such as terrorist attacks, floods, or earthquakes. Whereas cyber threats get increasing attention in the literature (Moore 2010), a discussion of climate change impacts is, for the most part, absent in civil security and critical infrastructure literature. One can conclude that, whereas the business management literature neglects the public dimension of climate change adaptation by businesses, the public management literature omits climate change as an issue for public security. The question of responsibility for climate change adaptation by private-sector critical infrastructure providers arises through bringing together findings from both literature streams. This is particularly relevant to those cases where adaptation measures are lacking or have been postponed.

\section{ALLOCATING RESPONSIBILITY}

Until a few decades ago, public utility services, including those providing critical infrastructures, were generally the domain of public entities. Today, most utility services are provided by the private sector. In developing countries, about 1,500 state-owned facilities, for example, energy and water services, were sold to private investors between 2000-2008 (World Bank 2012). In the United States today, $85 \%-90 \%$ of national assets are held by the private sector(Commission on Government Forecasting and Accountability 2006). This transfer of state tasks to the private sector, termed the "transformation of the state," (Lane 1997, Genschel and Zangel 2007, Dunn-Cavelty 2008, Schuppert 2009), can be seen as part of the conversion from a model of the state which provides services to the state as enabler. This shift was primarily caused by the need for cost reduction and improved private-sector competence in certain fields (Lane 1997, DunnCavelty 2008, Schuppert 2009). When former state tasks, especially those involving critical infrastructures, are transferred to private enterprises that postpone essential climate change adaptation measures, the question arises as to who bears responsibility for deficits or the failure of critical infrastructure service provision caused by climate change impacts. According to Genschel and Zangel (2007), de Bruijne and Van Eeten (2007), and Leibfried and Zürn (2005), the ultimate responsibility for provision of services that formerly resided with the state, remains with the state, given that the state continues to be responsible for public security. Simultaneously, businesses that supply services that were formerly in the public domain create societal objectives in cooperation with the state and other nonstate actors and, therefore, can be considered as "providers of governance." Zürcher (2007: 14-15) puts it as follows: "I suggest that we think of governance as a good produced by the state in association with 
Table 1. Results from literature review.

\begin{tabular}{ccc}
\hline \hline Source & Author, publication year & Focus \\
\hline
\end{tabular}

Business management literature

$\begin{array}{ll}\text { Ecological Economics } & \text { Frankhauser et al. } 1999 \\ & \text { Hasson et al. } 2010\end{array}$

Leclère et al. 2013

Business and Society

Linneluecke and Griffiths 2010

Thistlethwaite 2010

Furrer et al. 2012

\begin{abstract}
Business Strategy and Korhonen and Seager 2008 the Environment

Lucas 2010

Winn et al. 2010

Linneluecke et al. 2012

Weinhofer and Busch 2012
\end{abstract}

\author{
Long Range Planning Herbane et al. 2004 \\ Boiral 2006 \\ Engau and Hoffmann 2011
}

Climatic Change
(interdisciplinary)

Berkhout et al. 2006

Arnell and Delany 2006

Linneluecke and Griffiths 2012

Public management literature

$\begin{array}{ll}\begin{array}{l}\text { International Journal } \\ \text { of Critical }\end{array} & \text { Assaf } 2008 \\ \text { Infrastructure } & \text { Dunn-Cavelty and Suter } 2009 \\ \text { Protection } & \text { Moore 2010 }\end{array}$

Environment and $\quad$ Osberghaus et al. 2010

Planning $C$

Public Choice $\quad$ Montgomery and Bean 1999

Crettez and Deloche 2010
Public water supply in England and Wales provided by private companies

Insights for assessing organizational resilience to the effects of climate change

Rules to guide adaptation decisions

Climate change in a public goods game

Autonomous adaptation of European agricultural supply

Resilient companies in light of climatic extremes

Self-regulation in response to climate change risks in the insurance sector

How banks respond to climate change adaptation

Beyond eco-efficiency: a resilience perspective

Understanding private-sector environmental management practices

Climate change impacts on the private sector, deriving a conceptual foundation

Extreme weather events, importance of anticipatory private-sector adaptation

Empirical research on corporate strategies for managing climate risks

Role of business management continuity in the face of increasing threats Proactive vs. reactive adaptation measures

Exploring corporate strategies to cope with regulatory uncertainties inherent with climate change politics

Models of critical information infrastructure protection

PPP critique: expanded governance model on critical infrastructure protection Principles and policy options on cyber security

Role of government in climate change adaptation

Market failure, government failure, and the private supply of public goods Terrorism, key assets, and critical infrastructures to protect or to rebuild

Case study: Germany

Policy documents

COM 2009

BMI 2009

BMU 2008, 2011

BMI 2008

\section{Zeitschrift für Umweltpolitik und Umweltrecht}

Additional literature
Mahammadzadeh et al. 2008

Fichter and Stecher 2011

Pechan et al. 2011

Stecker et al. 2012, 2013
Adapting to climate change: towards a European framework for action National strategy for critical infrastructure protection

Adaptation strategy (2008) and adaptation action plan (2011)

Risk and crisis management: guide for companies and government authorities

Empirical research on private-sector adaptation

Empirical research on climate change strategies in the private sector

Empirical research on climate change adaptation by transport, energy sectors

Agenda setting for climate change adaptation and policy integration

Infrastructure privatization

Privatization

Role of government in adaptation and examples of adaptation measures

Adaptation policies

Privatization barometer 
other actors. There are abundant examples in which stateswhether intentionally or not - outsource the provision of basic functions to external actors." Thus, one can conclude that in the monopoly of responsibility for service provision of critical infrastructures, the responsibility of the state has not been replaced but, rather, supplemented by the private sector. The legitimacy and obligation of coordination, equalization of interests, and social justice remain public tasks, requiring effective interaction among public and private stakeholders. In the energy sector, for example, price oversight and regulatory arrangements are implemented in some countries to ensure security delivery.

In particular, [a] grid company is obliged by law to ensure the security of the network, i.e., the security of electricity supply. The costs are incorporated into the usage fees. In other words: specific regulation can be used to enforce security of supply in otherwise free markets, carefully trading off security against efficiency (Osberghaus et al. 2010).

The question that follows is how the state, which retains ultimate responsibility, can assure that private-sector critical infrastructure providers assume their responsibility for climate change adaptation.

\section{REGULATORY MODES FOR THE EXERCISE OF STATE RESPONSIBILITY}

If companies fail to undertake necessary climate change adaptation measures, the ultimate public sanction may be to withdraw their operating license (Fichter and Stecher 2011). However, this would not serve the purpose of ensuring public security if service provision were then to collapse in the absence of alternative suppliers. Instead, public entities could take over critical infrastructure provision themselves, provided that the competencies and resources were available. In some instances, communities have already taken over critical infrastructures by reverting to public ownership (re-municipalization). This is the case of water utilities in municipalities such as Paris, La Paz, and Atlanta, given negative outcomes of privatization such as increased tariffs and the failure to deliver promised improvements. Nonetheless, as competencies and resources were the driving reasons for privatization, it is unlikely that reverting to public ownership will be more than an exceptional case, given that $80 \%$ of critical infrastructures are now privately owned (Commission on Government Forecasting and Accountability 2006).

Even though the state holds ultimate responsibility for the continuity of critical infrastructures and consequently holds ultimate responsibility for climate change adaptation of privatesector providers of critical goods and services to the public, climate change adaptation measures depend on cooperation between the state and private enterprises. Although state actors are in a position of power to advance adaptation by private-sector critical infrastructure providers, given that the costs of reverting to public ownership generally exceed the budget of public actors, they are also highly dependent on private-sector cooperation. This power balance gives rise to a discussion of the theoretically possible options of regulatory modes with respect to any societal objective, ranging from command and control to free market solutions (based on Assaf 2008).

Concerning climate change adaptation, the choice of regulatory mode must reflect the state's position of ultimate responsibility, with the secondary responsibility for operations held by private enterprises. In the "command and control" mode, for example, the state would dictate exactly how particular critical infrastructures are to be protected from impacts of climate change. In the mode of "delegation to an agency," rule-making powers are delegated to public agencies, as the regulatory agency is presumed to have greater expertise and its independence would insulate it from political influence. In the case of climate change adaptation, "command and control" (legislation) and exclusive "delegation to an agency" should be rejected in favor of "delegation to an agency" and "negotiation," allowing for flexible adaptation measures. This is because the knowledge base about climate change impacts still involves considerable uncertainties, although it is constantly increasing (Frankenhauser et al. 1999, Young 2010). In addition, the spatial diversity of climate change impacts also leads to differential vulnerabilities and, therefore, tailor-made solutions are needed. "Delegation to an agency" along with "negotiation" is a mixed mode of public and private collaboration in rule making, monitoring, and enforcement, where the state, through a public agency, engages in consultation and perhaps even negotiation with regulated entities. Thus, direct regulations are tailored to individual firms or trade associations, who agree to work with the government to achieve common goals. Although the state retains its discretionary power, it seeks greater acceptance and hence, compliance, from the market. In keeping with the considerations detailed above, this mode fits best with critical infrastructure adaptation to climate change. The modes of "enforced self-regulation" and "self-regulation" are characterized by less prescription and either government facilitation of rules and standards or no government involvement, and do not take into account state responsibility for critical infrastructure protection. An example of these modes is The ClimateWise Principles, whereby the world's largest insurance companies govern their exposure to climate change risks through self-regulation. Therefore, modes close to "delegation to agency" and "negotiation" are advisable for climate change adaptation. An example is Public Private Partnerships (PPPs), which are characterized by complementary private and public actor objectives, mutual trust, clear strategies, clear distribution of risks, sharing of responsibilities and authority, and market- and success-oriented thinking (Dunn-Cavelty and Suter 2009). Rules for negotiation would have the objective of harnessing PPP risks of negative outcomes, attributed to the complexity of regulation in relation to other societal issues or the lack of public legitimacy given to private actors (Montgomery and Bean 1999, Assaf 2008, Dunn-Cavelty and Suter 2009).

In practice, the selection of regulatory modes may be influenced by a variety of factors, for example, the societal values of collectivism or individualism. Therefore, the following case study examines which modes of regulation are implemented by privatesector critical infrastructure providers adapting to climate change impacts. Germany is one of the leading countries in climate change adaptation, along with the Netherlands, Sweden, Norway, Australia, Canada, and the UK (Garrelts et al. 2011). This examination is based upon an explorative literature review of supranational and national policy documents addressing climate change adaptation. Additionally, results from empirical German research projects on climate change adaptation in the private sector are presented, for example, KLIMZUG (Fichter and Stecher 2011) and Chameleon (Stecker et al. 2011). 


\section{CASE STUDY: GERMANY}

\section{Critical infrastructures in Germany}

The privatization of critical infrastructures began in West Germany during the early 1960s, given rising costs in the public sector and the state's demand for financial resources. In 1983, when a federal conservative-liberal government came into power, the government under Chancellor Helmut Kohl began with the sale of shares of the energy and chemical company VEBA and the airline Deutsche Lufthansa. Additionally, the German postal and telecommunications sector were increasingly liberalized and reorganized from 1984 onward. A few years later, Berlin's water utility services were sold to private investors (Denkhaus and Schneider 1997). During the transition process from a centralized economic system in the former German Democratic Republic (East Germany) to the decentralized market system of the Federal Republic of Germany (West Germany), about 8,500 state-owned enterprises were split into nearly 14,000 companies, mainly for reasons of demonopolization, and had to be privatized within less than five years, from 1990-1995 (Denkhaus and Schneider 1997). In total, about 12,160 companies were sold to private investors for a total of EUR 33.23 billion (Fasbender 2004). In October 2005, a new government led by Chancellor Angela Merkel sold about 16\% of Frankfurt airport operator Fraport, followed by major sales of federal and state assets in 2006 (Privatization Barometer 2012). Today, more than $80 \%$ of critical infrastructures in Germany are owned and operated by the private sector (Denkhaus and Schneider 1997).

\section{Results from empirical research on adaptation to climate change} by private-sector critical infrastructure providers in Germany

Present results from empirical studies show maintenance of the status quo regarding private-sector climate change adaptation. In Germany, only a few empirical studies have been conducted that investigate climate change adaptation by private-sector critical infrastructure providers (see Günther 2009, Stecker et al. 2011). Both studies investigate adaption strategies in the German energy sector, and Stecker et al. (2011) additionally analyze the transport sector. Both empirical studies indicate that the respondents perceive an increase in extreme weather events in Germany. "About $40 \%$ of responses reveal that both the frequency and intensity have increased at the respective company's locations. The greatest trend towards a perceived increase in both cases was registered for heavy precipitation and storms, the least for extreme cold" (Stecker et al. 2011:21).

Nevertheless, only about $33 \%$ of respondents actually plan to implement adaptation measures (Stecker et al. 2011). An even lower percentage, of about $21 \%$, of energy and transport companies have actually implemented adaptation measures. Most of the responding companies (about 60\%) find themselves in the research or discussion stage (Stecker et al. 2011). Günther (2009) shows that enterprises in the energy sector strongly depend on regulatory measures. Given that the German climate change adaptation policy contains uncertainties, the energy sector is reluctant to implement adaptation measures.

Other empirical studies on climate change adaptation in the German private sector address companies, without making a distinction between critical and noncritical infrastructure providers (for example, Mahammadzadeh 2008, Fichter and Stecher 2011). Fichter and Stecher (2011) queried 4,000 companies located in Germany, which is the largest survey conducted to date in Germany. Although the study does not distinguish between critical infrastructures and noncritical infrastructures providers, it demonstrates how the private sector as a whole assesses the need for climate change adaptation. The results of this study show that most companies postpone climate change adaptation or rely on reactive adaptation measures, predominantly through insurance. At the same time, about 50\% of respondents indicate that considering climate change impacts to 2050 is an objective with considerable strategic relevance. With regards to the perception of responsibility for organizational adaptation to climate change, respondents expect cooperation between companies, chambers of commerce, and public actors.

As a result, all empirical studies show that, even though a majority of companies in Germany perceive the impacts of climate change and identify them to be strategically relevant, only a minority of both critical and noncritical infrastructure providers actually implement adaptation measures. Additionally, private-sector critical infrastructure providers in Germany prefer that "voluntary self-regulation" govern private sector adaptation to climate change.

\section{Regulatory modes applied in Germany}

This analysis of regulatory modes implemented in Germany is based on relevant policy documents and literature (Table 1). The multilevel governance of the European Union was accounted for in the European Union white paper Adapting to Climate Change: Towards a European Framework for Action (Commission of the European Communities 2009). The national-level analysis relied on the German Strategy for Adaptation to Climate Change (Federal Ministry for Environment, Nature Conservation and Nuclear Safety 2008), the action-based supplemental Adaptation Action Plan of the German Strategy for Adaptation to Climate Change (Federal Ministry for Environment, Nature Conservation, Building and Nuclear Safety 2011), the German National Strategy for Critical Infrastructure Protection, (Federal Ministry of the Interior 2008) and Protecting Critical Infrastructures-Risk and Crisis Management: A Guide for Companies and Government Authorities (Federal Ministry of the Interior 2008), developed with the cooperation of private-sector organizations and public authorities, for example, Fraport AG (logistics), Commerzbank, and the Cologne Police Headquarters. The core messages of these documents about responsibilities of public actors and privatesector critical infrastructure providers for climate change adaptation are summarized, followed by an analysis of which regulatory modes are planned or implemented.

The European white paper on climate change adaptation defines the role of public actors as supplying information on climate change and providing financial support to reduce uncertainties, and identifies information gaps and the financial constraints facing private actors in addressing adaptation (Commission of the European Communities 2009). Although the document states that "in comparison to reactive adaptation measures-preventive actions bring clear benefits," it does not account for a broad range of proactive adaptation measures, that is, adaptation space. Instead, it focuses on insurance as a proactive adaptation measure, without taking into account that insurance only serves to transfer risk to third parties. It scarcely addresses the proactive reduction of risks for societal benefit. The white paper explicitly mentions 
the special role of public actors with regards to private-sector climate change adaptation, but does not make a clear distinction between critical and noncritical infrastructure providers. Hence, this white paper indicates that market-based instruments and responsibility sharing are preferable modes for private-sector adaptation.

In any adaptation framework, consideration should be given to the role of specialized Market Based Instruments (MBIs) and public-private partnerships should be encouraged with a view to the sharing of investment, risk, reward and responsibilities between the public and private sector in the delivery of adaptation action (Commission of the European Communities 2009:14).

However, the white paper does not go into detail about how these objectives should be achieved.

At the national level, the German Strategy for Adaptation to Climate Change, developed by the Federal Ministry for the Environment, Nature Conservation and Nuclear Safety (2008), explicitly addresses the adaptation needs of critical infrastructures in Germany, recognizing their $>80 \%$ privatesector ownership. Hence, this German strategy stresses the need for negotiation between public and private actors for effective climate change adaptation. It further states that proactive adaptation measures are preferable and that the implementation of concrete adaptation options needs to be elaborated on, in cooperation with competent public authorities, the private sector, the scientific community, and other stakeholders. In fact, critical infrastructure protection is assigned to a variety of public authorities, for example, the Federal Ministry of the Interior, the Federal Ministry of Economics and Technology, and the Federal Ministry of Transport, Building and Urban Development. Given this situation of fragmented public responsibilities and a diverse array of objectives among public and private actors, the Federal Government also retains its right to mandate critical infrastructure adaptation through legislation, for example, by ordering energy companies to reduce power plant cooling water discharges into rivers in times of low precipitation.

The Adaptation Action Plan of the German Strategy for Adaptation to Climate Change developed by the Federal Ministry for the Environment, Nature Conservation and Nuclear Safety (2011), recognizes climate change adaptation as a private obligation, without making a distinction between critical and noncritical infrastructure providers. Its primary targets are medium-sized businesses, the insurance industry, and their stakeholders. According to this action plan, these enterprises ought to be supported in meeting industry-wide adaptation standards, and best practices should be shared through the Tatenbank database maintained by the Federal Environment Agency. An annex of the action plan provides an overview of adaptation strategies or policies and adaptation activities already undertaken. According to this annex, most German federal government ministries and their agencies advance climate change adaptation in the private sector through knowledge sharing, research projects, and standards improvement. Hence, it can be inferred that government authorities with responsibility for environmental issues prefer "negotiation" and "enforced selfregulation" for private-sector critical infrastructure provider climate change adaptation. Regulatory modes oriented towards "delegation to an agency" or "command and control" are not mentioned in the policy documents reviewed.

The German National Strategy on Critical Infrastructure Protection (2009), and Protecting Critical Infrastructures-Risk and Crisis Management: A Guide for Companies and Government Authorities (2008) have both been developed by the Federal Ministry of the Interior. Compared with the policy papers on climate change adaptation produced by the Federal Ministry for Environment, Nature Conservation and Nuclear Safety (2008, 2011), the German National Strategy on Critical Infrastructure Protection (Federal Ministry of the Interior 2009) does not differentiate between climate change impacts and other natural hazards and, therefore, does not account for climate change as a special societal issue, i.e., a novel phenomenon or a tipping point. Instead, the Federal Ministry of the Interior applies an allhazards approach. Hence, this strategy recommends addressing climate change impacts in the same manner as other natural hazards, which results in a risk culture where the state increasingly withdraws its resources and demands:

Open risk communication among the state, companies, citizens and the general public, taking account of the sensitivity of certain information; co-operation among all stakeholders in preventing and managing incidents; greater self-commitment by operators as regards incident prevention and management; a greater and self-reliant self-protection and self-help capability of individuals or institutions affected by the disruption or compromise of critical infrastructure services (Federal Ministry of the Interior 2009:11).

Consequently, this strategy relies on the cooperation between the federal government and its competent departments, privatesector critical infrastructure providers, and other stakeholders. This cooperative approach focuses on the exchange of "information among all parties involved and the development of action concepts coordinated with the relevant infrastructure providers and operators" (Federal Ministry of the Interior 2009:14). Additionally, the state reserves the right, and assumes its responsibility, "to optimize the protection of the respective infrastructure by amending existing legislation or enacting new legal regulations" (Federal Ministry of the Interior 2009:14). As a result, government authorities with responsibility for internal security prefer both "command and control" and "negotiation" as regulatory modes for climate change adaptation by privatesector critical infrastructure providers.

Protecting Critical Infrastructures-Risk and Crisis Management: A Guide for Companies and Government Authorities (Federal Ministry of the Interior 2011) explicitly addresses critical infrastructures provided by the private sector, and highlights the need to adapt proactively to a range of hazards, for example to natural disasters, technical or human failure, terrorist attacks, and war. The guide also assigns the ultimate responsibility for the provision of critical infrastructures to the state. At the same time, it only hesitantly acknowledges that climate change is already happening. Instead, it terms climate change impacts as being extreme weather events, even given the probability of their occurrence and their magnitude. 
Fig. 1. Critical infrastructure regulation for climate change adaptation in Germany.

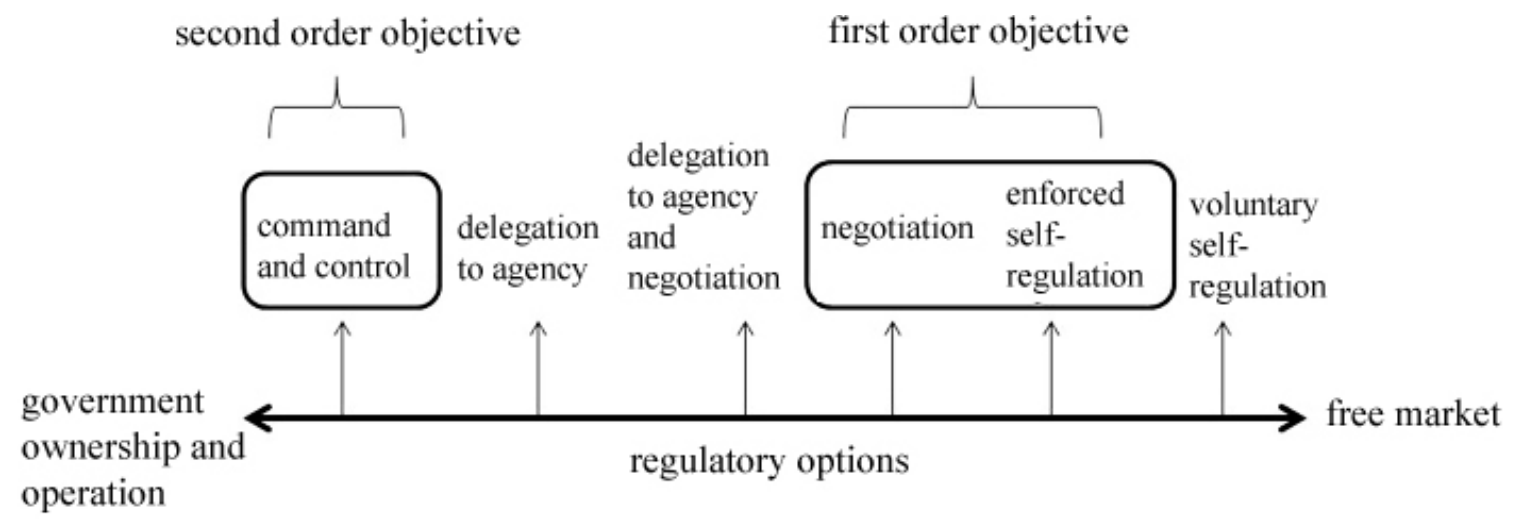

An analysis of these policy documents indicates that climate change adaptation is on the political agenda for private-sector critical infrastructure providers, with the preferred regulatory measure being proactive adaptation to climate change. Although these providers are reluctant to independently implement effective adaptation measures in a proactive manner, the Federal Ministry of the Environment and the Federal Ministry of the Interior proactively implement three regulatory objectives. Their preferred regulatory objectives are "negotiation" between public and private actors, to provide knowledge in terms of "enforced selfregulation." If these two regulatory objectives fail in practice, the state reserves the right to apply "command and control" measures through legislation. Figure 1 applies Assaf's (2008) theoretical framework to depict critical infrastructure regulation for climate change adaptation in Germany.

Interestingly, none of the documents analyzed considers "reverting to public ownership" as a regulatory objective for adaptation. This might be because of a lack of financial resources to repurchase critical infrastructures. The option of "delegation to a central agency" is also not mentioned in any of the policy papers. Instead, the Federal Ministries incorporate climate change adaptation by private-sector critical infrastructure providers into their respective areas of responsibility. For example, the Federal Ministry for Economics and Technology predominantly supports medium-sized industries, without addressing private-sector providers of critical infrastructures. The Federal Ministry of the Interior does not address climate change adaptation as a special societal issue but rather treats climate change as any other natural hazard.

\section{CONCLUSION}

Until now, the business management literature has focused on adaptation as a solely private good and, therefore, neglects the public dimension of climate change adaptation in the private sector, and particularly that of critical infrastructure providers. The business management literature on private-sector climate change adaptation predominantly neglects the fact that, in several countries around the world, more than $80 \%$ of critical infrastructures are delivered to the public by the private sector. Hence, public security depends on effective climate change adaptation by the private sector.
The application of these findings to the "transformation of the state" research field demonstrates that the former state monopoly on responsibility for service provision of critical infrastructures has largely been shifted to the private sector. Nevertheless, legitimization, and the obligation for coordination, equalization of interests, and social justice remain public responsibilities. Consequently, this constellation of private and public responsibilities requires close and intensive interactions between public and private stakeholders. These findings suggest "delegation to agency and negotiations" as a regulatory framework that both accounts for the state's position of ultimate responsibility and enables flexible, private-sector adaptation to climate change.

The German case study provided an analysis of how public and private actors' responsibilities are assumed, based on a review of relevant policy documents and additional literature. As expected, the analysis demonstrated that critical infrastructure providers prefer market-based instruments for climate change adaptation. Meanwhile, federal and state authorities implement three regulatory objectives: (1) "negotiation" between public and private actors; (2) the provision of knowledge in terms of "enforced self-regulation;" and (3) a reservation of the right to apply legislative "command and control" measures if these options fail. The case study also showed that, in Germany, public authorities do not account for the responsibility for climate change adaptation by private-sector critical infrastructure providers in a coordinated and comprehensive manner. Given the inadequate approach of the various relevant federal ministries (for example, the Federal Ministry for Economics and Technology, and the Federal Ministry of the Interior) to incorporating responsibility for climate change adaptation by private-sector critical infrastructure providers into their respective domains, this responsibility should be comprehensively delegated to an agency.

These findings raise the following questions as warranting further research: (1) What regulatory modes do other countries implement for climate change adaptation by private-sector critical infrastructure providers, and what lessons can be learned from the approaches of these other countries? (2) What lessons can be taken from dealing with other societal issues for climate change 
adaptation by private-sector critical infrastructure providers? (3) Which management capacities are required for climate change adaptation by private-sector critical infrastructure providers, with regards to meeting societal objectives such as justice and the equalization of private and public interests?

Responses to this article can be read online at: http://www.ecologyandsociety.org/issues/responses. $\mathrm{php} / 6282$

\section{Acknowledgments:}

This paper has been supported by the research project KLIMZUG nordwest2050, funded by the German Federal Ministry for Education and Research (2009-2014).

\section{LITERATURE CITED}

Aakre, S., and D. Rübbelke. 2010. Objectives of public economic policy and the adaptation to climate change. Journal of Environmental Planning and Management 53(6):767-791.

Assaf, D. 2008. Models of critical infrastructure protection. Journal of Critical Infrastructure Protection 1:6-14. http://dx.doi. org/10.1016/j.ijcip.2008.08.004

Arnell, N., and E.K. Delany. 2006. Adapting to climate change: public water supply in England and Wales. Climatic Change 78 (2-4):227-255. http://dx.doi.org/10.1007/s10584-006-9067-9

Barnett, J. 2003. Security and climate change. Global Environmental Change 13(1):7-7. http://dx.doi.org/10.1016/ S0959-3780(02)00080-8

Berkhout, F., J. Hertin, and D. M. Gann. 2006. Learning to adapt: organizational adaptation to climate change impacts. Climatic Change 78(1):135-156. http://dx.doi.org/10.1007/s10584-006-9089-3

Boiral, O. 2006. Global warming: should companies adapt proactive strategy? Long Range Planning 39(3):315-330. http:// dx.doi.org/10.1016/j.1rp.2006.07.002

Boin, A., and A. McConnell. 2007. Preparing for critical infrastructure breakdowns: the limits of crisis management and the need for resilience. Journal of Contingencies and Crisis Management 15(1):50-59. http://dx.doi.org/10.1111/

j.1468-5973.2007.00504.x

Commission of the European Communities (COM). 2009. White paper. Adapting to climate change: towards a European framework for action. Brussels, Belgium. [online] URL: http:// eur-lex.europa.eu/LexUriServ/LexUriServ.do?uri=COM:2009:0147: FIN:EN:PDF

Commission on Government Forecasting and Accountability (CGFA). 2006. Government privatization: history, issues, and examples. CGFA, Springfield, Illinois, USA. [online] URL: http:// cgfa.ilga.gov/Upload/2006Gov_Privatization_Rprt.pdf

Crettez, B., and R. Deloche. 2010. Terrorism, key assets, and critical infrastructures: to protect or to rebuild? That is the question. Public Choice 144(1-2):105-118. http://dx.doi. org/10.1007/s11127-009-9506-Z de Bruijne, M., and M. Van Eeten. 2007. Systems that should have failed: critical infrastructure protection in an institutionally fragmented environment. Journal of Contingencies and Crisis Management 15(1):18-29. http://dx.doi.org/10.1111/ j.1468-5973.2007.00501.x

Denkhaus, I., and V. Schneider. 1997. The privatization of infrastructures in Germany. Pages 64-114 in J. -E. Lane, editor. Public sector reform. Sage, London, UK. http://dx.doi. org/10.4135/9781446279274.n4

Dunn-Cavelty, M. 2008. Like a phoenix from the ashes: the reinvention of critical infrastructure protection a distributed security. Pages 40-62 in M. Dunn-Cavelty, and K. S. Kristensen, editors. Securing "the homeland." Routledge, New York, New York, USA. [online] URL: http://www.lrc.fema.gov/starweb/

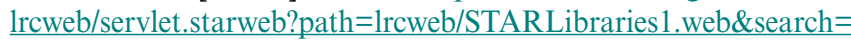
$\underline{\mathrm{R}=180646}$

Dunn-Cavelty, M., and M. Suter. 2009. Public-private partnerships are no silver bullet: an expanded governance model for critical infrastructure protection. Journal of Critical Infrastructure Protection 2(4):179-187. http://dx.doi.org/10.1016/ j.ijcip.2009.08.006

Engau, C., and V. Hoffmann. 2011. Strategizing in an unpredictable climate: exploring corporate strategies to cope with regulatory uncertainty. Long Range Planning 44(1):42-63. http:// dx.doi.org/10.1016/j.1rp.2010.11.003

Fasbender, K. 2004. Selected principles, elements and experiences of privatisation in Germany. Hamburg Institute of International Economics, Hamburg, Germany. [online] URL: http:// ageconsearch.umn.edu/bitstream/26102/1/re040245.pdf

Federal Ministry for the Environment, Nature Conservation and Nuclear Safety (BMU). 2008. German strategy for adaptation to climate change. Berlin, Germany. [online] URL: http://ccsl.iccip. net/das gesamt_en_bf.pdf

Federal Ministry for the Environment, Nature Conservation, Building and Nuclear Safety (BMUB). 2011. Adaptation action plan of the German strategy for adaptation to climate change. Berlin, Germany. [online] URL: http://www.bmub.bund.de/ fileadmin/bmu-import/files/pdfs/allgemein/application/pdf/ aktionsplan anpassung klimawandel en bf.pdf

Federal Ministry of the Interior (BMI). 2008. Protecting critical infrastructures — risk and crisis management: a guide for companies and government authorities. [online] URL: http://www.bmi.bund. de/SharedDocs/Downloads/EN/Broschueren/Leitfaden Schutzkritischer_Infrastrukturen_en.pdf? blob=publicationFile

Federal Ministry of the Interior (BMI). 2009. National strategy for critical infrastructure protection. BMI, Berlin, Germany. [online] URL: http://www.bmi.bund.de/cae/servlet/contentblob/598732/ publicationFile/34423/kritis englisch.pdf

Fichter, K., and T. Stecher. 2011. Klimaanpassung in der Wirtschaft: Ergebnisse einer Unternehmensbefragung. Zeitschrift für Umweltpolitik und Umweltrecht 34:249-278.

Frankhauser, S., J. B. Smith, and R. S. J. Tol. 1999. Weathering climate change; some simple rules to guide adaptation decisions. Ecological Economics 30(1):67-78. http://dx.doi.org/10.1016/ $\underline{\text { S0921-8009(98)00117-7 }}$ 
Furrer, B., J. Hamprecht, and V. H. Hoffmann. 2012. Much ado about nothing? How banks respond to climate change. Business and Society 51(1):62-88. http://dx.doi.org/10.1177/0007650311427428

Garrelts, H., K. Grecksch, and M. Winges. 2011. Adaptation policies in Germany. Handling adaptation governance choices in Sweden, Germany, the UK and the Netherlands. IVM Institute for Environmental Studies, VU University Amsterdam, Amsterdam, The Netherlands. [online] URL: http://dspace. library.uu.nl/bitstream/handle/1874/281472/Handling\%20adaptation $\%$ 20governance.pdf? sequence $=3$

Genschel, P., and B. Zangel. 2007. Die Zerfaserung von Staatlichkeit und die Zentralität des Staates. Aus Politik und Zeitgeschichte 20-21:10-16.

Günther, E. 2009. Klimawandel und Resilience Management: Interdisziplinäre Konzeption eines entscheidungsorientierten Ansatzes. Gabler Wissenschaft, Wiesbaden, Germany. http://dx. doi.org/10.1007/978-3-8349-8206-3

Hasson, R., A. Löfgren, and M. Visser. 2010. Climate change in a public goods game: investment decision in mitigation versus adaptation. Ecological Economics 70(2):331-338. http://dx.doi. org/10.1016/j.ecolecon.2010.09.004

Herbane, B., D. Elliott, and E. Swartz. 2004. Business continuity management: time for a strategic role? Long Range Planning 37 (5):435-457. http://dx.doi.org/10.1016/j.1rp.2004.07.011

Intergovernmental Panel on Climate Change (IPCC). 2007. Working Group II report. Impacts, adaptation and vulberability. Fourth assessment report of the Intergovernmental Panel on Climate Change. IPCC, Geneva, Switzerland.

Korhonen, J., and T. Saeger. 2008. Beyond eco-efficiency: a resilience perspective. Business Strategy and the Environment 17 (7):411-419. http://dx.doi.org/10.1002/bse.635

Privatization Barometer (PB). 2012. Germany: total privatization revenues and transactions. Fondazione Eni Enrico Mattei (FEEM) and KPMG Advisory S.p.A., Milan, Italy. [online] URL: http:// www.privatizationbarometer.net/atlas. $p h p ? i d=7 \& \mathrm{mn}=\mathrm{ST}$

Lane, J.-E. 1997. Public sector reform: only deregulation, privatization and marketization? Pages 1-17 in J.-E., Lane, editor. Public sector reform: rationale, trends, and problems. Sage, London, UK.

Leclère, D., P.-A. Jayet, and N. de Noblet-Ducoudré. 2013. Farmlevel autonomous adaptation of European agricultural supply to climate change. Ecological Economics 87:1-14. http://dx.doi. org/10.1016/j.ecolecon.2012.11.010

Leibfried, S., and M. Zürn, editors. 2005. Transformation of the state? Cambridge University Press, Cambridge, UK. http://dx. doi.org/10.1017/CBO9780511752193

Lewis, T. G. 2006. Infrastructure protection in homeland security. Defending a networked nation. Wiley, Hoboken, New Jersey, USA. http://dx.doi.org/10.1002/0471789542

Linnenluecke, M. K., and A. Griffiths. 2010. Beyond adaptation: resilience for business in light of climate change and weather extremes. Business and Society 49(3):477-511. http://dx.doi. org/10.1177/0007650310368814
Linnenluecke, M. K., A. Griffiths, and M. Winn. 2012. Extreme weather events and the critical importance of anticipatory adaptation and organizational resilience in responding to impacts. Business Strategy and the Environment 21(1):17-32. http://dx.doi.org/10.1002/bse.708

Lucas, M. 2010. Understanding environmental management practices: integrating views from strategic management and ecological economics. Business Strategy and the Environment 19 (8):543-556. http://dx.doi.org/10.1002/bse.662

Mahammadzadeh, M., J.-F. Selke, and H. Biebeler. 2008. Rohstoffverknappung, demographischer Wandel und Klimawandel als globale Herausforderungen für Unternehmen-Ergebnisse einer Unternehmensbefragung. Zeitschrift für Umweltpolitik und Umweltrecht 31:541-566.

Montgomery, M., and R. Bean. 1999. Market failure, government failure, and the private supply of public goods: the case of climatecontrolled walkway networks. Public Choice 99(3-4):403-437. http://dx.doi.org/10.1023/A:1018301628084

Moore, T. 2010. The economics of cyber security: principles and policy options. Journal of Critical Infrastructure Protection 3(34):103-117. http://dx.doi.org/10.1016/j.ijcip.2010.10.002

Osberghaus, D., A. Dannenberg, and T. Mennel. 2010. The role of the government in adaptation to climate change. Environment and Planning C: Government and Policy 28(5):834-850. http://dx. doi.org/10.1068/c09179j

Ostrom, V., and E. Ostrom. 1997. Public goods and public choices. Pages 7-49 in E. S. Savas, editor. Alternatives for delivering public services: towards improved performance. Westview, Boulder, Colorado, USA.

Pechan, A., M. Rotter, and K. Eisenack. 2011. Eingestellt auf Klimafolgen? Ergebnisse einer Unternehmensbefragung zur Anpassung in der Energie- und Verkehrswirtschaft. Schriftenreihe des Instituts für Ökologische Wirtschaftsforng 11.

Schuppert, F. G., editor. 2009. Von der Ko-Produktion von Staatlichkeit zur Co-Performance von Governance. Eine Skizze zu kooperativen Governance-Strukturen von den Condottieri der italienischen Renaissance bis hin zu Public Private Partnerships. Pages 285-320 in S. Botzem, J. Hofmann, S. Qauck, G.F. Schuppert, and H. Straßheim, editors. Governance als Prozess. Schriften zu Governanceforschung 16. Nomos, Baden-Baden, Germany.

Sheffi, Y. 2005. The resilient enterprise. The MIT Press, Cambridge, Massachusetts, USA.

Stecher, T., and K. Fichter 2010. Anpassung an den Klimawandel als betriebswirtschaftliche Herausforderung: eine Journalauswertung. Umweltwirtschaftsforum 18(1):53-60. http://dx.doi.org/10.1007/ s00550-010-0166-8

Stecker, R., A. Pechan, J. M. Steinhäuser, M. Rotter, G. Scholl, and K. Eisenack. 2011. Why are utilities reluctant to adapt to climate change? Chameleon Research Group, University of Oldenburg, Oldenburg, Germany. [online] URL: http://www. ioew.de/uploads/tx_ukioewdb/Why_are_Utilities_Reluctant_to_Adapt to Climate Change.pdf 
Stecker, R., T. Mohn, and K. Eisenack. 2013. Adaptation to climate change - agenda setting and policy integration in Germany.

Chameleon Research Group, University of Oldenburg, Oldenburg, Germany. [online] URL: http://www.climatechameleon.de/htm engl/documents/Steckeretal AdaptationtoClimateChangeinGermany.pdf

Tagarev, T., and N. Pavlov 2007. Planning measures and capabilities for protection of critical infrastructures. Information and Security 22:38-48.

Termeer, C., A. Dewulf, H. Van Rijswick, A. Van Buuren, D. Huitema, S. Meijerink, T. Rayner, and M. Wiering. 2011. The regional governance of climate adaptation: a framework for developing legitimate, effective, and resilient governance arrangements. Climate Law 2:159-179.

Thistlethwaite, J. 2010. The ClimateWise principles: selfregulating climate change risks in the insurance sector. Business and Society 51(1):121-147. http://dx.doi.org/10.1177/0007650311427595

Tompkins, E., and H. Eakin. 2012. Managing private and public adaptation to climate change. Global Environmental Change 22 (1):3-11. http://dx.doi.org/10.1016/j.gloenvcha.2011.09.010

Van der Lei, T. E., G. Bekebrede, and I. Nikoloc. 2010. Critical infrastructures: a review from a complex adaptive systems perspective. Journal of Critical Infrastructure 4:380-401.

Weinhofer, G., and T. Busch. 2012. Corporate strategies for managing climate risks. Business Strategy and the Environment. 22(2):121-144. [online] URL: http://onlinelibrary.wiley.com/ doi/10.1002/bse.1744/full

Winn, M., M. Kirchgeorg, A. Griffiths, M. K. Linnenluecke, and E. Günther. 2010. Impacts from climate change on organizations: a conceptual foundation. Business Strategy and the Environment. 20(3)157-173.

World Bank. 2012. Privatization. Washington, D.C., USA. [online] URL: http://web.worldbank.org/WBSITE/EXTERNAL/ TOPICS/EXTFINANCIALSECTOR/0, contentMDK:22936580 menuPK:7994350 pagePK:210058 piPK:210062 theSitePK:282885,00. $\underline{\mathrm{html}}$

Young, O. R. 2010. Institutional dynamics: emergent patterns in international environmental governance. Cambridge, London, UK.

Zürcher, C. 2007. When governance meets troubled states. Pages 11-27 in M. Beinsheim, and G. F. Schuppert, editors. Staatszerfall und Governance. Nomos, Baden-Baden, Germany. 